Earnings Differentials between the Public and the Private Sectors in China: Explaining Changing Trends for Urban Locals in the 2000s

Juan Yang, Sylvie Démurger, Shi Li

Décembre 2010 


\section{GATE Groupe d'Analyse et de Théorie Économique Lyon-St Étienne}

93, chemin des Mouilles 69130 Ecully - France

Tel. +33 (0)4 72866060

Fax $+33(0) 472866090$

6, rue Basse des Rives 42023 Saint-Etienne cedex 02 - France

Tel. +33 (0)4 77421960

Fax. $+33(0) 477421950$

Messagerie électronique / Email : gate@gate.cnrs.fr

Téléchargement / Download : http://www.gate.cnrs.fr - Publications / Working Papers 


\title{
Earnings Differentials between the Public and the Private Sectors in China: Explaining Changing Trends for Urban Locals in the 2000s
}

\author{
Juan Yang \\ School of Economics and Business Administration \\ Beijing Normal University, 19, Xinjiekouwai Dajie, Beijing 100875, China \\ E-mail: yangjuan@bnu.edu.cn
}

Sylvie Démurger

Université de Lyon, Lyon, F-69003, France

CNRS, GATE Lyon St Etienne, 93 Chemin des Mouilles, Ecully, F-69130, France $\&$

CNRS, CEFC, USR 3331 Asie Orientale, Hong Kong

E-mail: demurger@gate.cnrs.fr

\author{
Shi Li \\ School of Economics and Business Administration \\ Beijing Normal University, 19, Xinjiekouwai Dajie, Beijing 100875, China \\ Email: lishi@bnu.edu.cn
}

This version: December 2010

\begin{abstract}
This paper analyzes the changes in public-private sector earnings differentials for local residents in urban China between 2002 and 2007. We find that earnings gaps across ownership have been reducing during this period and that the convergence trend has been in favor of the private and semi-public sectors as opposed to the public sector. This is in sharp contrast to what occurred at the turn of the century, when employees of public administration and enterprises were found to enjoy a very much privileged situation. On the one hand, differences in endowments are found to play a growing role in explaining earnings differentials. On the other hand, although starting to become less an issue, segmentation across ownership remains important, especially for high-wage earners.
\end{abstract}

Key words: labor market, earnings differentials, segmentation, enterprise ownership, China.

JEL classification: J31, J42, P23, O53. 


\section{Introduction}

Three decades of economic reform have brought tremendous changes in every sector of China's economy. The labor market is no exception, and it has been particularly affected by important policy and institutional changes at the turn of the century. On the one hand, the state sector reform was speeded up after the Chinese Communist Party's 15th Congress held in September 1997, which encouraged both the corporatization of large state-owned enterprises (SOEs) and the restructuring of small SOEs. On the other hand, the same Congress recognized private enterprises as an important component of the economy and stressed the rule of law. As a direct consequence, the urban labor market has been reshaped through the unprecedented growth in unemployment and the reallocation of labor from the public to the private sector. In the meantime, competition among workers in the urban labor market has sharply increased on account of a massive rural labor force exodus, which led an estimated 140 million rural workers to move to cities by 2008 .

In the context of a transitional economy, these dramatic changes raise a number of issues on the direction toward which the urban labor market is moving. A key aspect to be explored is whether the labor market has transformed into a market-oriented one and whether enterprises with different ownership operate in a competitive way. Academic research conducted on data collected from the mid-nineties to the very beginning of the twenty-first century highlights the incompleteness of the reforms and the "unfinished economic revolution" (Lardy, 1998) as well as the remaining rigidities in a segmented labor market made up of several segments with distinct rules for wage determination and a limited mobility of labor between segments (e.g. Chen, Démurger and Fournier 2005; Démurger et al. 2007a; Dong and Bowles 2002; Knight and Song 2003; Li and Bai 2005). Evidence on micro data from the mid-nineties shows that workers in the public sector had very limited incentives to move out and that one of the main reasons for this immobility was the higher-than-market-clearing-level earnings premium provided to workers in state-owned units (Chen et al. 2005; Zhao 2002). Moreover, for the period from 1995 to 2002, Démurger et al. (2007a) find strong evidence of increasing segmentation across ownership with the gap between the privileged segments of the labor market and the most competitive segments widening over time. 
Policy-related rationales for studying labor market segmentation issues are related to both efficiency, as illustrated by the literature on the public-private sector earnings gap in developing countries or economies in transition (Adamchik and Bedi 2000; Boeri and Terell 2002; Falaris 2004; Lokshin and Jovanovic 2003) and income inequality (Meng and Zhang 2001). A multi-tiered labor market in which wages are not only determined by skill differentials, but also by different institutional arrangements may have strong implications in terms of both labor allocation across sectors and income distribution among workers. In China, where the so-called iron rice bowl (tiefanwan) of lifetime employment with the associated welfare state had dominated for years before it was completely dismantled in 1994 (Knight and Song 2005), the issue of the public sector efficiency also appears of special importance. Moreover, the question of income distribution is essential to any government concerned with smooth economic development and social safety. With the growth of China's economy and rising average wages, earnings gap triggered a vigorous debate in China. In this context, ownership is also a fairly important question since it is linked with the issue of whether the government can provide an equal and efficient business environment for all sorts of companies to develop and maximize social welfare. Given that the number of enterprises in the public sector decreased from about $99 \%$ of total companies in 1978 to merely $10 \%$ in 2007 , it is also interesting to explore whether the remaining public sector still enjoys a privileged position in the labor market through particular government policies.

Macroeconomic data on average wages of staff and workers in urban China show an increasing trend since the mid-nineties (Figure 1). The average wage in 2007 was 2,060 Yuan a month, 5.7 times higher than the figure in 1995 (in constant 2007 prices). Although the increase has been rapid for every type of ownership, some discrepancies emerged over time, the most remarkable being a narrowing gap between the public and the private sectors. Indeed, while average wages in 1995 were the highest in the "other ownership" (private sector) category, they turned to be lower than in the SOEs in 2007. Similarly, the College Students Employment Survey organized by Peking University on more than 100 universities in 2002 and 2007 shows that while the first employment intention in 2002 was to work in foreign-invested enterprises, it turned to SOEs in 2007. This change 
calls for further research to find out the reason behind this and more precisely to investigate whether it is due to any discriminating behavior or specific power of certain types of enterprises.

The release of new data from the Project on Rural-Urban Migration in China (RUMIC-2007) in 2008 makes it possible to analyze whether China's labor market is still segmented by ownership in terms of earnings differentials. The comprehensive information on personal characteristics provided by available micro datasets (RUMIC-2007 and CHIP-2002) enables us to investigate wage compensation by controlling individuals' most important characteristics. Previous researches on China's labor market segmentation all utilize data for the year 2002 or before. However, during the period of 2002-07, China's economic growth averaged $10.8 \%$ in real terms and China has become increasingly integrated into global markets, especially after joining the World Trade Organization in 2001. In addition, private companies have been allowed to enter the previously state-controlled areas, such as steel, aluminum and car business in recent years, and private high technological enterprises, especially internet companies are soaring and many of them went to the public and developed into top 500 companies in China. This implies that the old-style companies like state-owned enterprises and urban collective companies have to compete with market-oriented companies, including private companies, joint-venture companies, or foreign companies in a more intensive way.

Under intensified economic reforms between 2002 and 2007, we propose to investigate the trend and the determinants of earnings gap across ownership during this period. We first analyze average gaps by using the Oaxaca-Blinder decomposition technique, and then account for different patterns in different percentile for different ownership by applying the Juhn-Murphy-Pierce decomposition method.

The remainder of the paper is organized as follows: Section 2 describes the development of various types of enterprises in China. Section 3 introduces the dataset along with some descriptive statistics. Section 4 discusses econometric results on earnings equations by enterprise ownership. Section 5 and Section 6 present decomposition results of earnings gaps across ownership during 2002-07. Section 7 concludes. 


\section{Economic reforms and the evolution of ownership}

After China became a socialist country in 1949 , most of the means of production belonged to the state, and private and individual economic activities were made illegal. Therefore, within the first five-year plan period, the percentage of public ownership increased from $21.3 \%$ in 1952 to $92.9 \%$ in 1956. When the economic reforms started in 1978, the national economy was strongly dominated by public ownership, which was composed of state-owned companies and collective enterprises. State-owned companies and collective enterprises accounted for respectively $24 \%$ and $76 \%$ of the total number of industrial companies, and $78 \%$ and $22 \%$ of the total industrial production.

One major aspect of the economic reform was to encourage the development of the non-state sector in the economy. Through revising a series of laws and regulations, the government gradually allowed private and foreign companies to co-exist with state-owned and collective companies. In 1988, the State Council issued the "Tentative Stipulations on Private Enterprises" to govern the registration and management of private firms, and in 1993, the Company Law provided the legal framework for the development of limited liability companies and shareholding companies (Démurger et al. 2007a). Hence, various forms of non-public ownership such as private-owned, foreign-invested, joint-venture, share-holding, stock companies and self-employed became alternatives to former state-owned companies. More recently, efforts have been made to ensure a fairer competition between the public and the private sectors and to open more industries to the private sector. In 2003, new regulations allowed non-state enterprises to enter steel, aluminum and even some part of the national defense industries. In February 2005, the State Council issued "36 Suggestions to Encourage and Support Non-State-Owned Economic Development" in order to reduce barriers to market entry and to stimulate private investment.

The development of the non-state sector helped promoting competition among all the companies as well as allocating the resources more efficiently. Before the reform, since the resources were allocated according to the plan and the economy was dominated by public ownership, there was no competition among enterprises or employees. Allowing private and foreign companies to enter the labor market made it possible to improve the national economy as a whole and to promote prosperity. 
The other advantage was the alleviation of the employment pressure. With the baby boom and soldiers transferring to non-military sectors, the newly increasing labor force reached more than 10 million every year and the non-state sector became a major channel to absorb the growing labor force.

Hence, whereas employment in the public sector had kept rising continuously until the mid-nineties, it started to decrease in 1995 , with a huge acceleration in $1998(-18 \%)$, the pivotal year in SOEs reforms. Since then, the number of workers in both SOEs and urban collective enterprises (UCEs) kept decreasing, from 144.6 million in 1995 to 71.4 million in 2007 (National Bureau of Statistics 2008), a total decrease of fifty percent. The public sector share in urban employment dropped from $76 \%$ to $24 \%$ over the same period. In contrast to the downsizing of the public sector, the private sector share in urban employment has increased from $16 \%$ in 1995 to $42 \%$ in 2007 . The dramatic increase of the private sector share in urban employment can be attributed to the development of both private or individual enterprises and foreign-invested enterprises, as well as to the emergence of new forms of ownership from the mid-nineties onward, including limited liability corporations and share-holding corporations. From 1995 to 2007, employment in foreign-invested enterprises tripled (from 5.1 million to 25.8 million) and employment in private and individual enterprises almost quadrupled (from 20.4 million to 78.9 million). Moreover, the number of people employed in new ownership forms multiplied by ten, from 3.2 million in 1995 to 30.8 million in 2007. All these figures clearly indicate a significant shift in the employment structure at the turn of the century, China experiencing a situation somewhat similar to Eastern European countries in the process of moving the labor force from the public to the private sector.

\section{Data and descriptive analysis}

\subsection{Summary statistics by ownership}

The data used in this paper comes from two sources: the Chinese Household Income Project carried out in 2003 for the year 2002 (CHIP-2002 hereafter) and the Project on Rural-Urban Migration in China (RUMIC-2007 hereafter) carried out in 2008 for the year 2007. For both surveys, the questionnaire was designed by Chinese and foreign researchers and implemented by China's National 
Bureau of Statistics (NBS) ${ }^{1}$. The two datasets all include three separate surveys: urban, rural and migrant. In this analysis, we employ the urban survey that covers urban residents only $^{2}$. The CHIP-2002 urban survey was collected from 6,835 households with a population of 20,632 in twelve provinces, and the RUMIC-2007 urban survey was collected from 5,003 households with a population of 14,699 in nine provinces.

For the sake of comparison, we keep only the jointly surveyed seven provinces' observations in our sample. The seven provinces are Jiangsu, Anhui, Henan, Hubei, Guangdong, Chongqing and Sichuan. In addition, we further restrict the sample to individuals aged between 16 and 60 for men and between 16 to 55 for women with full-time employment and earning positive wages ${ }^{3}$. The final sample size amounts to 5,430 workers for 2002 and to 5,029 workers for 2007 .

The enterprise ownership analyzed in the paper is divided into five categories (see Table 1): state-owned enterprises (SOEs), government agencies or institutions (GAIs), urban collective enterprises (UCEs), private or individual enterprises (PIEs), and foreign-invested enterprises (FIEs). A comparison between 2002 and 2007 shows opposite trends for the public and the private sectors: the share of SOEs decreased from $35 \%$ to $19 \%$, while the share of PIEs increased from $24 \%$ to $33 \%$ (Table 2). This may raise another issue on how to classify enterprises according to their ownership. In each survey, respondents were required to answer which ownership their company belongs to. In CHIP-2002, the ownership was separated into 13 types, and in 2007 it was separated into 16 types. In order to simplify the analysis, we group these different types into five categories only. The "SOEs" category thus contains state-owned enterprises, state-controlled enterprises, and state-owned joint ventures. In other words, as long as the state-share is in a dominant position, no matter who owns the

\footnotetext{
${ }^{1}$ Although the sampling design for both surveys is based on that of the annual urban household survey conducted by the NBS, there is one discrepancy between the two datasets that is worth mentioning here. Indeed, the RUMIC-2007 data were collected from the NBS new sample. The sampled households, who entered the survey in 2008, reported their income by recalling, unlike households in the 2002 survey, who had recorded income. According to NBS, recalled income might be less accurate than recorded income. It is unfortunately not possible to provide robustness checks on this issue, but we believe that given the scope of the identified effects in our analysis, the bias, if any, should not be too strong.

${ }^{2}$ Urban residents are people living in cities, who hold an urban household registration (hukou). Unregistered urban workers such as rural migrants are not included in this dataset.

${ }^{3}$ After restricting the sample to full-time employment, the minimal age of the sample increased to 18 . One may argue that, with the expansion of higher education, most of individuals aged 18-22 are still at school and this could result in sample selection bias. However in RUMIC-2007, the percentage of individuals aged 18-22 who are still at school account for only $3.6 \%$ of this age group and the percentage is even lower in 2002. Hence, such a bias, if any, should not affect our estimation results too much.
} 
other shares (including foreigners or Chinese private investors), the enterprise will fall into the SOEs category in our analysis. On the other hand, we only classify the foreign solely invested companies and foreign-owned joint-venture companies as FIEs. This classification choice may explain why, despite foreign direct investment increased substantially from 2002 to 2007, the share of FIEs in our analysis does not change significantly.

\section{$<$ Insert Table $1>$}

Descriptive statistics on individual characteristics by different ownership are shown in Table 2 . The gender distribution does not change much across years, with males representing $56-57 \%$ of urban workers and being particularly concentrated in SOEs where they account for respectively $59.5 \%$ and $61.5 \%$ of the total in 2002 and 2007 . To some extent, this distribution suggests that male may enjoy some advantages in recruitment and income in the public sector as compared to females. Yet, a noteworthy change between 2002 and 2007 occurred for UCEs where females were traditionally over-represented (Démurger, Chen and Fournier 2007b; Maurer-Fazio, Rawski and Zhang 1999). In 2007, males account for $53.7 \%$ of workers in UCEs, against $44 \%$ only in 2002 . While it is still the lowest share of males across ownership, the difference is now not significant anymore with other categories (apart from SOEs). As documented further below, this change reflects an improving situation of UCEs, where increased competition may have boosted productivity and attracted more talented workers.

\section{$<$ Insert Table $2>$}

The comparison between 2002 and 2007 shows a slight decrease in the average age of the workforce that is more marked in UCEs and in the private sector than in the public sector (SOEs and GAIs). In both years, the public sector employs older workers than the private sector does. As expected with the expansion of higher education after 1999, the average educational attainment of the workforce, measured in years of schooling, has substantially increased over time, by almost one year in the 5-year period (from 11.34 years to 12.22 years). Except GAIs, which were employing the most educated workers in $2002^{4}$, each ownership category has benefited from the increase in the education

\footnotetext{
${ }^{4}$ In 2002, the average education level of workers in GAIs was more than 12 years of schooling, which was much higher than in any other type of enterprise.
} 
level so that the absolute gap in educational attainment of workers across ownership has reduced from 2.56 years to 2.09 years. The evolution indicates that besides public administration, FIEs are more and more able to attract talented youngsters in 2007.

The average experience in the current job (expressed in years) is much shorter in 2007 for all the sectors except GAIs than in 2002. The sharpest decreases occurred for the semi-public sector (UCEs) and for the private sector (both PIEs and FIEs). This evolution probably signals increased job mobility in these sectors, while jobs in the public sector (SOEs and GAIs) are still the most stable ones and individuals would not easily leave their positions there. Finally, the average size of companies experienced a decreasing trend between 2002 and 2007, with the largest enterprises being found in both SOEs and FIEs.

\subsection{The evolution of earnings and their distribution by ownership}

Table 3 reports summary statistics on earnings by ownership. Total annual earnings are composed of reported wages, bonuses, in-kind earnings, subsidies, pension income, etc. Hourly earnings are calculated by dividing total annual earnings by the number of declared hours worked in a year. In addition, earnings are adjusted for provincial purchasing power differences by using an updated set of Brandt and Holz (2006) urban provincial-level spatial price deflators in order to account for differences in living standards across cities.

\section{$<$ Insert Table $3>$}

In the five-year period from 2002 to 2007 , earnings differentials between enterprises of different ownership have changed markedly. Real earnings have almost doubled on average, but at a different pace across enterprises. The state sector experienced the slowest growth in annual and hourly earnings (88-92\% for SOEs, and $62-63 \%$ for GAIs), and on the contrary both UCEs and the private sector experienced earnings increase of more than $110 \%$ (up to a maximum $138 \%$ for hourly earnings in UCEs). As opposed to what occurred between 1995 and 2002 (Démurger et al. 2007a), differentials across enterprises have somehow re-adjusted towards more equality thanks to the dramatic increase of earnings in both UCEs and PIEs. While total earnings were the highest in GAIs in 2002, the much slower earnings increase in GAIs between 2002 and 2007 moved them down to the second rank after 
FIEs $^{5}$. On the other hand, UCEs as well as PIEs have seen their relative position dramatically improving (again as opposed to what occurred between 1995 and 2002), the gap to average total earnings reducing from 0.7 to 0.86 for UCEs and from 0.81 to 0.94 for PIEs. Last, SOEs stand in the middle and the almost doubling of earnings in this part of the state sector allowed workers to maintain their intermediate position, with a gap to average earnings very close to one for the two years ${ }^{6}$.

Another interesting point concerns the on-going convergence of working time between the public and the private sectors. As for the period from 1995 to 2002, the number of hours worked per week continued to decrease in both PIEs and FIEs. On the other hand, the working time slightly increased in the public sector, although it remains shorter than in the private sector in 2007. One possible reason of the convergence is that on the one hand, the competition in SOEs and GAIs sectors has become more and more intensive and employees may have to work harder to maintain their position. On the other hand, PIEs and FIEs started to pay more attention to employees' rights.

Gini coefficients highlight a general trend of increasing annual and hourly earnings inequality. For the whole sample, the Gini coefficient for hourly earnings has increased from 0.367 to 0.405 between 2002 and 2007. Although PIEs continuously exhibit the largest earnings dispersion over time ${ }^{7}$, the increase in earnings inequality has been more pronounced in the public sector (including UCEs), which resulted in a convergence of earnings distributions across sectors between 2002 and 2007.

Non-parametric kernel density estimations for the distribution of the logarithm of hourly earnings by ownership category and by year are presented in Figure 2. For each year, the graph shows the distribution for the whole sample as well as for ownership category subsamples.

$$
<\text { Insert Figure } 2>
$$

The upper panel of Figure 2 displays kernel density estimates for the year 2002. Hourly earnings in GAIs are on average higher than in other sectors, which can be seen in both a position of the curve

\footnotetext{
${ }^{5}$ Interestingly, this movement is a complete reversal as compared to the period from 1995 to 2002 (see Démurger et al. 2007a).

${ }^{6}$ One should note though that reported earnings may not fully reflect actual individuals' income in the state sector, which may result in an underestimation of earnings in this sector. Indeed, the welfare system in SOEs and GAIs is still much better than in FIEs and PIEs, but it is hard to collect all the information on this part, especially regarding the non-pecuniary welfare. Given the comparatively high wages in these two sectors, plus non-observable income, jobs in SOEs and GAIs can still be as attractive as, or even more attractive than jobs in FIEs.

${ }^{7}$ This trend confirms the more unequal distribution of hourly wages in the private sector as compared to the public sector that had been observed in the nineties (see Chen et al. 2005; Xing 2008).
} 
most to the right and a higher kurtosis. In addition, the spread is very narrow and highly concentrated around the mean. FIEs come second, with average earnings only a little bit higher than in SOEs but with a larger width that illustrates a wider distribution. The hourly wages in PIEs are the lowest among the five sectors, with a distribution skewed to the right, which indicates that some earnings in PIEs are fairly low.

As illustrated in the bottom panel of Figure 2, patterns have not changed much over time, except that the five lines seem closer in 2007 as compared to 2002. This further illustrates the converging trend of the hourly earnings gap among the five sectors. In 2007, FIEs exhibit characteristics in hourly wages distributions more desirable than GAIs do. Together with higher average hourly earnings, FIEs also exhibit a very flat tail in the left part of the distribution, indicating that there are not many low-wage earners in this sector ${ }^{8}$. Moreover, the distributions for GAIs and UCEs are quite similar, except that the hourly wages distribution of GAIs is on the right of that of UCEs. Finally the kurtosis is the highest in SOEs, suggesting a sharper peak and fatter tails of hourly earnings distribution in the state sector.

\section{The determinants of hourly earnings}

Tables 4 and 5 present OLS estimations of an augmented Mincerian hourly earnings function (Mincer 1974) run separately by enterprise ownership and by year'. The Mincerian earnings equation takes the following form:

$$
w_{i r}=\beta_{i r} X_{i r}+u_{i r}
$$

where subscript $r \in[1,5]$ represents the five different ownership categories defined above. $w_{i r}$ is the natural logarithm of hourly earnings (adjusted for provincial purchasing power differences) for individual $i$ in enterprise $r . X_{i r}$ is a vector of her individual characteristics and $\beta$ gives the set of returns to each observed socio-demographic characteristic. $X$ includes gender, education (measured in years of

\footnotetext{
${ }^{8}$ This may reflect our ownership classification. Indeed, FIEs only include foreign-owned enterprises and foreign-controlled enterprises, which are mainly concentrated in higher-end industries.

${ }^{9}$ Card (1999) provides a brief introduction of all kinds of estimating methods and their respective advantages and disadvantages on the return to education. He advocates that OLS estimating method is still the most robust technique.
} 
schooling as reported in the surveys), work experience ${ }^{10}$ and its square, work experience in the current occupation, on-the-job training (dummy variable), regional dummies for coastal provinces and for capital cities, and company size. The residual $u_{i r}$ stands for all the unobservable factors that may affect individual hourly earnings $w$.

\section{$<$ Insert Table $4>$ \\ $<$ Insert Table $5>$}

Returns to education are significant in all sectors for both years. They are much higher in both GAIs and FIEs than in any other sector. A comparison over time also reveals interesting changes. Indeed, returns to education exhibit an increasing trend in UCEs, FIEs and GAIs between 2002 and 2007, but a decreasing trend in both SOEs and PIEs that resulted in a growing gap across sectors. Hence, the range of returns to education depending on enterprise ownership moved from $5.64 \%-8.57 \%$ in 2002 to $3.81 \%-9.04 \%$ in 2007 .

Linear and quadratic terms in experience are significant in the public sector (SOEs and GAIs) as well as in the private sector (PIEs), but non-significant in both UCEs and FIEs for both 2002 and 2007. As discussed in Chen et al. (2005), the observed difference in experience earnings profiles between the public sector and other sectors suggests that in SOEs and GAIs, seniority remains an important component in the determination of wages. Interestingly, experience is also important in the private sector though. A comparison between 2002 and 2007 shows much earlier earnings peaks for the year 2007, which suggests that older people have seen their relative position deteriorating over time. Indeed, whatever the enterprise, the experience profile starts decreasing after 20 years of experience, while it was decreasing after 30 years of experience in 2002. The introduction of another indicator of experience that measures the number of years in the company adds some interesting results for foreign-invested firms. Indeed, the associated coefficient turns out to be significant in 2007 , thus suggesting that the experience that counts for FIEs is experience accumulated in the enterprise rather than the overall experience (which may have been accumulated in the less efficient public or semi-public sectors).

\footnotetext{
${ }^{10}$ The actual work experience is not reported in the 2007 survey. As a consequence, we use potential work experience, defined as age minus years in school minus six.
} 
Returns to gender also exhibit noteworthy differences across ownership and over time. In 2002, being a male in PIEs increased log hourly wages by about $21.9 \%$ while the increase was only $7 \%$ in GAIs. The "male premium" increased dramatically over time, especially in the public and the semi-public sectors, and reached levels comprised between $16.5 \%$ (in GAIs) and 25\% (in PIEs). This partly reflects the findings by Song and Li (2010) that gender wage inequality increased during the period 2002-07. Interestingly, FIEs do not appear to favor males more than females since the coefficient for the gender dummy is never significant.

Finally, the coefficient estimates for being located in a coastal province (Beijing, Jiangsu or Guangdong) show a premium of living in the coast in all enterprises but FIEs in both years. The comparison of coefficients over time suggests an increasing "coastal premium" for SOEs and UCEs, and a slightly decreasing premium for PIEs.

\section{Oaxaca-Blinder decompositions}

In order to analyze earnings differentials between individuals belonging to different enterprises, we first use the Oaxaca-Blinder method (Blinder 1973; Oaxaca 1973) to decompose mean differences in log earnings into two components: one attributable to the differences in mean endowments of workers across ownership, and one attributable to differences in returns to these endowments.

The observed average log earnings difference between two enterprises of different ownership, $r_{l}$ and $r_{2}$, can be defined as:

$$
\Delta \bar{w}_{r_{1} r_{2}}=\bar{w}_{r_{1}}-\bar{w}_{r_{2}}
$$

where bars indicate mean values. Substituting equation (1) into (2) yields:

$$
\Delta \bar{w}_{r_{1} r_{2}}=\bar{X}_{r_{1}}^{\prime} \hat{\beta}_{r_{1}}-\bar{X}_{r_{2}}^{\prime} \hat{\beta}_{r_{2}}
$$

where hats denote estimated coefficients from separate earnings equations.

Assuming that a non-discriminatory wage structure $\beta^{*}$ is known, the log wage differential can be decomposed in the following way (Neumark 1988):

$$
\Delta \bar{w}_{r_{1} r_{2}}=\left(\bar{X}_{r_{1}}-\bar{X}_{r_{2}}\right)^{\prime} \beta^{*}+\left[\bar{X}_{r_{1}}^{\prime}\left(\hat{\beta}_{r_{1}}-\beta^{*}\right)-\bar{X}_{r_{2}}^{\prime}\left(\hat{\beta}_{r_{2}}-\beta^{*}\right)\right]
$$


Equation (4) shows that the earnings gap between ownership $r_{1}$ and ownership $r_{2}$ can be decomposed into two parts. The first term can be interpreted as the part of the log earnings differential due to differences in average individual characteristics between different ownerships. It measures how much individuals in ownership $r_{l}$ would earn if they had the same characteristics as those in ownership $r_{2}$. The second term represents the amount by which earnings between two different ownerships differ from the assumed non-discriminatory wage structure. It is the "unexplained" or residual component of the earnings gap. This effect can be interpreted either as the part due to segmentation or to different productivity levels. In other words, the fact that individuals with the same characteristics are paid differently in different ownership might be due to different production processes that result in different individual productivity across ownership, or to particular institutional factors, such as monopolistic power that lead to the return gap. There are several ways of constructing the assumed non-discriminatory wage structure $\beta^{*}$ (Jann 2008). In what follows, we present decompositions using the method proposed by Neumark (1988), which assumes a pooled wage structure (including a group indicator as suggested by Jann (2008)) as the non-discriminatory wage structure.

Table 6 reports the changes in relative remunerations across enterprises of different ownership in urban China, by applying the Oaxaca-Blinder decomposition method separately for the year 2002 and the year 2007. The table presents the mean predictions by ownership group, their difference, and the decomposition of the difference into the explained and the unexplained parts (expressed in both mean value and in percentage of the mean difference).

\section{$<$ Insert Table $6>$}

The top panel in Table 6 shows the log hourly earnings decomposition results by ownership for the year 2002. Earnings gaps are rather large, especially between the public sector and PIEs, as well as between FIEs and PIEs. In addition, except for the gap between SOEs and FIEs, all ownership differences are significantly different from zero. The results of the decomposition reveal that differences in endowment account for a rather small share of the earnings gap for all pairs of sectors, except for the pairs UCEs-PIEs and PIEs-FIEs. Hence, in 2002, the unexplained part accounted for most of the observed difference, which corroborates Démurger et al. (2007a)'s finding that segmentation effect across ownership is fairly serious in urban China. The most striking example of 
such segmentation can be observed within the public sector: differences in endowments between SOEs and GAIs are negligible and the 27 percent earnings gap is entirely due to the "unexplained" component, which probably reflects the very strong institutional protection of workers in GAIs at the turn of the century (Démurger et al. 2007a). The same applies between GAIs and FIEs, the former clearly appearing as a protected sector as compared to the foreign sector.

Compared to the year 2002, the log hourly earnings gaps across ownership in 2007 have substantially reduced for all pairs of sectors, except between SOEs and FIEs as well as between GAIs and FIEs, for which the gap turned significantly in favor of FIEs. The evolution has been generally in favor of both the private and the semi-public sectors (PIEs, FIEs and UCEs), and at the expense of the public sector, mostly GAIs which had gained a lot during the period from 1995 and 2002. As already observed in the descriptive part of the paper, the trend during the period from 2002 to 2007 has thus been toward a rebalancing between the different ownerships.

The pattern of decomposition across ownership also changed remarkably between 2002 and 2007, with a striking reversal in contributions of the explained and the unexplained parts in earnings differentials. Differences in endowment gained importance in accounting for earnings gaps in 2007 as well as for the general decreasing trend in earnings differences across ownership, while segmentation started to become less an issue.

The decomposition analysis presented in Table 6 highlights three main phenomena on the ownership dimension, which are of importance to understand the recent evolution of the labor market in urban China. First, both urban collectives and private enterprises have seen their relative position dramatically improving as compared to the public sector. Indeed, compared to both SOEs and GAIs, the huge decrease in the earnings gap comes from two concomitant forces: a convergence in endowments on the one hand, and a sharp reduction of segmentation against UCEs and PIEs on the other hand. This change is important in the sense that it signals a better integration of the domestic sectors -public, semi-public or private-, which never occurred before.

Second, although the dominant position of GAIs has been diminishing between 2002 and 2007, the comparatively still higher wages in GAIs may be attributed more importantly to employees' better endowments as compared to other sectors. This is especially the case when compared to UCEs and 
PIEs: differences in endowments account respectively for $50 \%$ and $67 \%$ of the earnings gap with GAIs in 2007 while the shares were only $12 \%$ and $27 \%$ in 2002 . Say differently, the strong increase in segmentation in favor of GAIs that had been observed in the early 2000s (Démurger et al. 2007a) is vanishing in the recent period both in absolute terms and as a share of log earnings differences, which may indicate a trend toward less protection of earnings in the public sector.

Third, the foreign sector continued to reinforce its position through both better characteristics as well as more pronounced segmentation, especially as compared to the public sector. Interestingly, the sharp increase in the earnings gap between SOEs and FIEs (in favor of the latter) between 2002 and 2007 comes from both diverging characteristics (that explain almost half the gap in 2007) and increasing segmentation. In 2007, if there were no differences in characteristics with SOEs, the premium for FIEs would be 13\%. A similar magnitude of the premium coming from the "unexplained" part applies to the difference with GAIs, which explains the entire gap since FIEs and GAIs workers' characteristics are very close. Finally, compared with UCEs and PIEs, the position of FIEs has not changed much: both better characteristics in FIEs and a rather strong segmentation contribute almost equally to still important earnings gaps of $37 \%$ with UCEs and $47 \%$ with FIEs.

\section{Juhn-Murphy-Pierce decomposition}

The Oaxaca-Blinder decomposition approach only deals with the mean of the distribution and ignores differences along the distribution like its dispersion or skewness. However, as shown in Section 3, the distribution of hourly earnings differs across sectors. Hence, to complement the Oaxaca-Blinder decomposition, we use the decomposition technique proposed by Juhn, Murphy and Pierce (1993) that takes account of the whole earnings distribution.

The Juhn-Murphy-Pierce decomposition method extends the Oaxaca-Blinder approach by accounting for the residual distribution so that the hourly earnings gap can be decomposed into three parts: the individual characteristics effect (resulting from a change in the distribution of the $X \mathrm{~s}$ ), the return or "price" effect (resulting from a change in the $\beta \mathrm{s}$ ) and the residual effect (or unobservable factors' influence). 
Following Juhn et al. (1993), the residual $u_{i r}$ in equation (1) can be written as follows:

$$
u_{i r}=F_{r}^{-1}\left(\theta_{i r} \mid X_{i r}\right)
$$

where $\theta_{i r}$ is the percentile of an individual in the residual distribution, and $F_{r}$ is the cumulative distribution function of the earnings equation residuals (for individuals with characteristics $X_{i r}$ in ownership $r$ ).

Assuming that $F^{*}$ is a reference residual distribution and $\beta^{*}$ a reference wage structure ${ }^{11}$, two hypothetical hourly earnings distribution can be created as follows:

$$
\begin{aligned}
& w_{i r_{1}}^{1}=\beta^{*} X_{i r_{1}}+F^{*-1}\left(\theta_{i r_{1}} \mid X_{i r_{1}}\right) \\
& w_{i r_{1}}^{2}=\beta^{r_{1}} X_{i r_{1}}+F^{*-1}\left(\theta_{i r_{1}} \mid X_{i r_{1}}\right)
\end{aligned}
$$

The first hypothetical set of wages given in equation (6) is computed by valuing each worker's characteristics $X_{i r_{1}}$ in sector $r_{l}$ at the reference wage structure $\beta^{*}$ and her position in sector $r_{l}$ 's residual distribution at the corresponding position in the reference residual distribution $F^{*}$. The second hypothetical distribution for sector $r_{1}$ given in equation (7) results from giving each worker her own estimated returns to characteristics $\beta^{r_{1}}$ but the reference residual distribution $F^{*}$.

The main feature of the Juhn-Murphy-Pierce decomposition approach is that it allows an analysis over the whole earnings distribution. If the notation $\widetilde{w}$ stands for a summary statistic of the distribution of the corresponding variable, one can then write the following decomposition of the log earnings difference between two enterprises of different ownership, $r_{1}$ and $r_{2}$ :

$$
\widetilde{w}_{r_{1}}-\widetilde{w}_{r_{2}}=\widetilde{w}_{r_{1}}^{1}-\widetilde{w}_{r_{2}}^{1}+\left[\left(\widetilde{w}_{r_{1}}^{2}-\widetilde{w}_{r_{2}}^{2}\right)-\left(\widetilde{w}_{r_{1}}^{1}-\widetilde{w}_{r_{2}}^{1}\right)\right]+\left[\left(\widetilde{w}_{r_{1}}-\widetilde{w}_{r_{2}}\right)-\left(\widetilde{w}_{r_{1}}^{2}-\widetilde{w}_{r_{2}}^{2}\right)\right]
$$

Given the definitions above, the first right-hand side term simply reflects the individual characteristics effect, or the difference in observable quantities between the two sectors. The second term (into brackets) represents the return effect, or the difference in observable prices, and the third term represents the residual effect, expressed by the difference of two sectors' residual distribution.

$$
<\text { Insert Figure } 3>
$$

\footnotetext{
${ }^{11}$ As for the Oaxaca-Blinder decomposition, the reference wage structure is estimated from a pooled model over the whole sample. The reference residual distribution is the average distribution over both samples. Decomposition results presented here are generated using the jmpierce.ado program for Stata.
} 
Results of Juhn-Murphy-Pierce decompositions for each pair of ownership are displayed in Figure 3. Each sub-figure presents the earnings gap as well as its decomposition for a pair of ownership at various percentiles: $5^{\text {th }}, 10^{\text {th }}, 25^{\text {th }}, 50^{\text {th }}, 75^{\text {th }}, 90^{\text {th }}$ and $95^{\text {th }}$. Four main observations can be drawn from these figures.

First, the distribution of earnings gaps varies markedly across pairs of ownership. The comparison of any ownership with the domestic private sector (that is the pairs SOEs-PIEs, GAIs-PIEs, UCEs-PIEs, and FIEs-PIES) shows that the largest gap occurs at the bottom of the distribution but it almost vanishes at the top of the distribution in both 2002 and 2007. This means that the significant average earnings gaps observed between these categories of ownership are mainly due to the bottom 5-10 percentile individuals, with the private sector paying much less than any other category. On the other hand, the pattern is completely reversed when comparing UCEs and FIEs in 2002: the earnings gap for the lowest wage-earners is fairly small and it significantly increases when moving up the income distribution. This trend reflects the patterns observed in Figure 2, with "high-wage" earners in the foreign sector receiving a much higher remuneration than "high-wage" earners in the semi-public sector in 2002. Finally, the profile for the earning gaps between SOEs and UCEs, between GAIs and UCEs, as well as between SOEs and GAIs is rather flat in 2002. This indicates comparatively fairly equal distributions of earnings gaps within the public and semi-public sectors, the difference between the top and bottom percentiles being not substantial.

Second, the decomposition of the earnings gaps confirms that individual endowments only explain a small share of the observed gaps within the public and semi-public sectors (SOEs, GAIs, and UCEs), while the segmentation (or price) effect is the largest, with no significant variations over the distribution. When it comes to a comparison with the private sector, the quantity component becomes relatively more important, and explains about half the earnings difference between FIEs and UCEs, and between FIEs and PIEs. Finally, the residual effect (unobserved factors) does not play any clear-cut role in explaining earnings difference, except at the bottom of the distribution for the pairs SOEs-PIEs, GAIs-PIEs and UCEs-PIEs.

Third, the comparison between SOEs and FIEs deserves some specific comments because the gap varies a lot over the earnings distribution and important changes occurred over time. In 2002, SOEs 
were paying comparatively higher average wages to lowest-wage earners, while FIEs were offering higher wages to the $75^{\text {th }}$ percentile, which made the gap changing sign over the distribution (and may explain why the mean difference reported in Table 6 is not significant). Interestingly, while the gap in favor of SOEs at the bottom of the distribution appears to be equally explained by differences in quantity, price and residuals, the gap in favor of FIEs at the top of the distribution is mainly explained by different remuneration of characteristics (that more than compensate better characteristics for SOEs workers).

Fourth, as previously discussed, earnings differentials have substantially reduced between 2002 and 2007 for almost all pairs of sectors. Whole distributions provide a more complete view of this average evolution by highlighting some differences along the earnings distribution. Hence, the reduction in earnings gap tends to be more pronounced at the bottom of the distribution, thanks to a decreasing segmentation. This is particularly the case for the pairs SOEs-GAIs and UCEs-GAIs, suggesting that in the public sector, the wage structure has become more harmonized for the low-wage earners. In addition, distribution patterns for different ownerships at various percentiles have changed a lot, suggesting that wage setting mechanisms have experienced great changes during this period. In this respect, the foreign sector exhibits particularly interesting changes. Indeed, FIEs have clearly improved their position relative to both SOEs and GAIs, with a gap being now fully in favor of FIEs over the whole distribution, and with very clear differences at the top of the distribution, almost fully explained by segmentation in favor of FIEs. This probably reflects a proactive strategy from FIEs toward high-wage earners (that was already visible in 2002, although less clear-cut). Interestingly, the tiniest earnings differential for the pairs FIEs-SOEs and FIEs-GAIs is around the $25^{\text {th }}$ percentile, which indicates that for individuals below the median, wages across these ownerships are quite similar. Finally, the 2007 graphs also indicate that segmentation still plays a fairly important role in explaining earnings gaps across ownership, with a particularly pronounced importance at the top of the distribution. 


\section{Conclusion}

This paper analyzes wages inequality trends across ownership for the period 2002-07 and investigates the reasons behind the gap by decomposing the mean wages difference using Oaxaca-Blinder technique and analyzing the wages gap distribution using Juhn-Murphy-Pierce decomposition method.

We find that while average earnings gaps were still fairly large across ownership sectors in 2002, they have reduced over the five-year period to 2007. Moreover, the observed earnings convergence took place in favor of the private and semi-public public sectors, as opposed to the public sector. In terms of earnings differentials across the distribution, the Juhn-Murphy-Pierce decomposition highlights a comparatively fairly equal distribution within the public sector while most of the gap for the private domestic sector comes from the bottom of the distribution. As for foreign-invested enterprises, the clear improvement of their position with regard to the public sector (SOEs and GAIs) between 2002 and 2007 is observable over the whole distribution, which implies that workers in foreign-invested firms have all benefited from the improved position of these enterprises.

Both Oaxaca-Blinder and Juhn-Murphy-Pierce decompositions show that differences in endowments gained importance over time in accounting for earnings gaps as well as for the general decreasing trend in earnings differences across ownership. On the other hand, segmentation started to become less an issue in 2007 as compared to 2002. Indeed, our results highlight a better integration of domestic sectors that never occurred before. They also show that the segmentation in favor of GAIs, which was fairly strong in 2002, has been vanishing over time, although not throughout the whole distribution. In particular, Juhn-Murphy-Pierce decompositions indicate that segmentation remains important for high-wage earners, which suggests that workers at the top of the distribution are still benefiting from some protection as compared to workers at the low-end. 


\section{References}

Adamchick, V. A. and A. S. Bedi (2000), "Wage differentials between the public and the private sectors: Evidence from an economy in transition”, Labour Economics, 7(2), 203-224.

Blinder, A. S. (1973), "Wage Discrimination: Reduced Form and Structural Estimates", Journal of Human Resources, 8(4), 436-55.

Boeri, T. and K. Terell (2002), "Institutional Determinants of Labor Reallocation in Transition", Journal of Economic Perspectives, 16(1), 51-76.

Brandt, L. and C. A. Holz (2006), "Spatial Price Differences in China: Estimates and Implications", Economic Development and Cultural Change, 55(1), 43-86.

Card, D. (1999), “The causal effect of education on earnings", in O. Ashenfelter and D. Card (eds.), Handbook of Labor Economics, North Holland, Amsterdam, Vol. 3, 1801-1863.

Chen, Y., S. Démurger, and M. Fournier (2005), "Earnings differentials and ownership structure in Chinese enterprises," Economic Development and Cultural Change, 53(4), 933-958.

Démurger, S., M. Fournier, S. Li, and Z. Wei (2007a), "Economic liberalization with rising segmentation on China's urban labor market," Asian Economic Papers, 5(3), 58-101.

Démurger, S., M. Fournier, and Y. Chen (2007b), "The Evolution of Gender Earnings Gaps and Discrimination in Urban China: 1988-1995,” The Developing Economies, 45(1), 97-121.

Dong, X. and P. Bowles (2002), "Segmentation and discrimination in China's emerging industrial labor market," China Economic Review, 13(2-3), 170-196.

Falaris, E. M. (2004), "Private and public sector wages in Bulgaria", Journal of Comparative Economics, 32(1), 56-72.

Jann, B. (2008), “A Stata implementation of the Blinder-Oaxaca decomposition,” ETH Zurich Sociology Working Papers 5, ETH Zurich.

Juhn, C, K. Murphy, and B. Pierce (1993), "Wage inequality and the rise in returns to skill," Journal of Political Economy, 101, 410-442.

Knight, J. and L. Song (2005), Towards a Labour Market in China, Oxford: Oxford University Press.

Knight, J. and L. Song (2003), "Increasing urban wage inequality in China: Extent, elements and 
evaluation", Economics of Transition, 11(4), 597-619.

Lardy N. R. (1998), China’s Unfinished Economic Revolution, The Brookings Institution.

Li, S. and N. Bai (2005), China Human Development Report - Development with Equity, Beijing: UNDP and China Development Research Foundation.

Lokshin M. M. and B. Jovanovic (2003), "Wage differentials and state private sector employment choice in Yugoslavia", Economics of Transition, 11(3), 463-491.

Maurer-Fazio, M., T. Rawski, and W. Zhang (1999), "Inequality in the rewards for holding up half the sky: gender wage gaps in China's urban labor market, 1988-1994,” China Journal, 41, 55-88.

Meng, X. and J. Zhang (2001), “The two-tier labor market in urban China - Occupational Segregation and Wage Differentials between Urban Residents and Rural Migrants in Shanghai," Journal of Comparative Economics, 29(3), 485-504.

Mincer, J. (1974), Schooling, experience, and earnings, New York: National Bureau of Economic Research.

Neumark, D. (1988), “Employers' Discriminatory Behavior and the Estimation of Wage Discrimination", The Journal of Human Resources, 23, 279-295.

Oaxaca, R. L. (1973), "Male-Female Wage Differentials in Urban Labor Markets," International Economic Review, 14(3), 693-709.

Song, J. and S. Li, (2010), "Changes in gender wage gap in urban China during 1995-2007", conference paper for the inequality workshop, BNU, China.

Xing, C. (2008), "Human Capital and Wage Determination in Different Ownerships, 1989-97", in Wan Guanghua (ed.), Understanding Inequality and Poverty in China: Methods and Applications, Palgrave Macmillan.

Zhao, Y. (2002), "Earnings differentials between state and non-state enterprises in urban China," Pacific Economic Review, 7(1), 181-197. 
Table 1 - Definition of ownership categories

\begin{tabular}{|c|c|c|}
\hline $\begin{array}{l}\text { Public versus private } \\
\text { groups }\end{array}$ & Ownership categories & Types included \\
\hline \multirow[t]{2}{*}{ Public sector } & State-owned enterprises (SOEs) & $\begin{array}{l}\text { Solely state owned enterprises; } \\
\text { State holding enterprises; } \\
\text { State holding joint venture. }\end{array}$ \\
\hline & $\begin{array}{l}\text { Government agencies and } \\
\text { institutions (GAIs) }\end{array}$ & $\begin{array}{l}\text { Government agencies and Party agencies } \\
\text { (including the Party Committee, Government, } \\
\text { People's Congress, the Chinese People's Political } \\
\text { Consultative Conference (CPPCC), Public security } \\
\text { organs \& Procurator's offices \& courts, The } \\
\text { Ministry of Armed Forces, Army); } \\
\text { State and collective institutions; } \\
\text { Civilian-run enterprises and public service unit. }\end{array}$ \\
\hline Semi-public sector & $\begin{array}{l}\text { Urban collective enterprises } \\
\text { (UCEs) }\end{array}$ & $\begin{array}{l}\text { Solely collective owned enterprise; } \\
\text { Collective holding enterprises; } \\
\text { Collective holding joint venture. }\end{array}$ \\
\hline \multirow[t]{2}{*}{ Private sector } & $\begin{array}{l}\text { Private and individual } \\
\text { enterprises (PIEs) }\end{array}$ & $\begin{array}{l}\text { Solely private owned enterprises; } \\
\text { Private holding enterprises; } \\
\text { Private holding joint venture; } \\
\text { Self-employed Individuals. }\end{array}$ \\
\hline & $\begin{array}{l}\text { Foreign-invested enterprises } \\
\text { (FIEs) }\end{array}$ & $\begin{array}{l}\text { Solely foreign owned enterprises; } \\
\text { Foreign holding joint venture. }\end{array}$ \\
\hline
\end{tabular}

Source: RUMIC-2007 urban survey questionnaire.

Note: if the answer given by the respondent is "Other enterprises", then it is not attributed to any of the above category and simply dropped. 
Table 2 - Descriptive statistics on individual characteristics by ownership

\begin{tabular}{|c|c|c|c|c|c|c|}
\hline 2002 & SOES & GAIs & UCEs & PIEs & FIEs & All \\
\hline Gender & $\begin{array}{c}0.595 \\
(0.491)\end{array}$ & $\begin{array}{c}0.551 \\
(0.498)\end{array}$ & $\begin{array}{c}0.440 \\
(0.497)\end{array}$ & $\begin{array}{c}0.549 \\
(0.498)\end{array}$ & $\begin{array}{c}0.567 \\
(0.497)\end{array}$ & $\begin{array}{c}0.558 \\
(0.497)\end{array}$ \\
\hline Age & $\begin{array}{c}40.86 \\
(8.505)\end{array}$ & $\begin{array}{c}40.46 \\
(8.914)\end{array}$ & $\begin{array}{c}41.44 \\
(8.178)\end{array}$ & $\begin{array}{c}39.11 \\
(8.666)\end{array}$ & $\begin{array}{c}35.85 \\
(8.923)\end{array}$ & $\begin{array}{c}40.24 \\
(8.716)\end{array}$ \\
\hline Education & $\begin{array}{c}11.17 \\
(2.702)\end{array}$ & $\begin{array}{c}12.69 \\
(2.872)\end{array}$ & $\begin{array}{c}10.13 \\
(2.471)\end{array}$ & $\begin{array}{c}10.14 \\
(2.853)\end{array}$ & $\begin{array}{c}11.96 \\
(2.665)\end{array}$ & $\begin{array}{c}11.34 \\
(2.957)\end{array}$ \\
\hline Experience in current job & $\begin{array}{c}17.71 \\
(9.383)\end{array}$ & $\begin{array}{c}14.43 \\
(9.214)\end{array}$ & $\begin{array}{c}16.25 \\
(9.380)\end{array}$ & $\begin{array}{c}10.45 \\
(9.335)\end{array}$ & $\begin{array}{c}10.46 \\
(8.417)\end{array}$ & $\begin{array}{c}14.65 \\
(9.722)\end{array}$ \\
\hline Training & $\begin{array}{c}0.283 \\
(0.451)\end{array}$ & $\begin{array}{c}0.327 \\
(0.469)\end{array}$ & $\begin{array}{c}0.239 \\
(0.427)\end{array}$ & $\begin{array}{c}0.198 \\
(0.398)\end{array}$ & $\begin{array}{c}0.276 \\
(0.449)\end{array}$ & $\begin{array}{c}0.273 \\
(0.445)\end{array}$ \\
\hline Coast & $\begin{array}{c}0.308 \\
(0.462)\end{array}$ & $\begin{array}{c}0.294 \\
(0.456)\end{array}$ & $\begin{array}{c}0.450 \\
(0.498)\end{array}$ & $\begin{array}{c}0.363 \\
(0.481)\end{array}$ & $\begin{array}{c}0.504 \\
(0.502)\end{array}$ & $\begin{array}{c}0.332 \\
(0.471)\end{array}$ \\
\hline Capital city & $\begin{array}{c}0.348 \\
(0.476)\end{array}$ & $\begin{array}{c}0.305 \\
(0.461)\end{array}$ & $\begin{array}{c}0.232 \\
(0.422)\end{array}$ & $\begin{array}{c}0.236 \\
(0.425)\end{array}$ & $\begin{array}{c}0.488 \\
(0.502)\end{array}$ & $\begin{array}{c}0.302 \\
(0.459)\end{array}$ \\
\hline Company size & $\begin{array}{c}2.912 \\
(1.129)\end{array}$ & $\begin{array}{c}1.793 \\
(1.013)\end{array}$ & $\begin{array}{c}1.919 \\
(0.968)\end{array}$ & $\begin{array}{c}1.752 \\
(1.069)\end{array}$ & $\begin{array}{c}2.709 \\
(1.062)\end{array}$ & $\begin{array}{c}2.204 \\
(1.194)\end{array}$ \\
\hline $\begin{array}{c}\text { Observations } \\
\% \text { of total }\end{array}$ & $\begin{array}{l}1896 \\
34.92\end{array}$ & $\begin{array}{l}1698 \\
31.27\end{array}$ & $\begin{array}{c}393 \\
7.24\end{array}$ & $\begin{array}{l}1316 \\
24.24\end{array}$ & $\begin{array}{c}127 \\
2.34\end{array}$ & $\begin{array}{c}5430 \\
100.00\end{array}$ \\
\hline 2007 & SOEs & GAIs & UCEs & PIEs & FIEs & All \\
\hline Gender & $\begin{array}{c}0.615 \\
(0.487)\end{array}$ & $\begin{array}{c}0.570 \\
(0.495)\end{array}$ & $\begin{array}{c}0.537 \\
(0.500)\end{array}$ & $\begin{array}{c}0.555 \\
(0.497)\end{array}$ & $\begin{array}{c}0.558 \\
(0.498)\end{array}$ & $\begin{array}{c}0.571 \\
(0.495)\end{array}$ \\
\hline Age & $\begin{array}{c}40.56 \\
(9.258)\end{array}$ & $\begin{array}{c}40.59 \\
(9.332)\end{array}$ & $\begin{array}{c}39.52 \\
(9.118)\end{array}$ & $\begin{array}{c}37.93 \\
(9.236)\end{array}$ & $\begin{array}{c}34.17 \\
(7.748)\end{array}$ & $\begin{array}{c}39.43 \\
(9.353)\end{array}$ \\
\hline Education & $\begin{array}{c}12.14 \\
(3.032)\end{array}$ & $\begin{array}{c}12.99 \\
(3.076)\end{array}$ & $\begin{array}{c}11.78 \\
(3.116)\end{array}$ & $\begin{array}{c}11.30 \\
(3.232)\end{array}$ & $\begin{array}{c}13.39 \\
(3.211)\end{array}$ & $\begin{array}{c}12.22 \\
(3.215)\end{array}$ \\
\hline Experience in current job & $\begin{array}{c}16.99 \\
(10.72)\end{array}$ & $\begin{array}{c}14.85 \\
(10.63)\end{array}$ & $\begin{array}{c}12.48 \\
(10.19)\end{array}$ & $\begin{array}{c}8.606 \\
(8.115)\end{array}$ & $\begin{array}{c}8.628 \\
(7.126)\end{array}$ & $\begin{array}{c}12.85 \\
(10.32)\end{array}$ \\
\hline Training & $\begin{array}{c}0.442 \\
(0.497)\end{array}$ & $\begin{array}{c}0.425 \\
(0.494)\end{array}$ & $\begin{array}{c}0.326 \\
(0.470)\end{array}$ & $\begin{array}{c}0.275 \\
(0.447)\end{array}$ & $\begin{array}{c}0.407 \\
(0.493)\end{array}$ & $\begin{array}{c}0.372 \\
(0.484)\end{array}$ \\
\hline Coast & $\begin{array}{c}0.248 \\
(0.432)\end{array}$ & $\begin{array}{c}0.321 \\
(0.467)\end{array}$ & $\begin{array}{c}0.389 \\
(0.488)\end{array}$ & $\begin{array}{c}0.398 \\
(0.490)\end{array}$ & $\begin{array}{c}0.628 \\
(0.485)\end{array}$ & $\begin{array}{c}0.347 \\
(0.476)\end{array}$ \\
\hline Capital city & $\begin{array}{c}0.673 \\
(0.469)\end{array}$ & $\begin{array}{c}0.664 \\
(0.473)\end{array}$ & $\begin{array}{c}0.646 \\
(0.479)\end{array}$ & $\begin{array}{c}0.606 \\
(0.489)\end{array}$ & $\begin{array}{c}0.512 \\
(0.501)\end{array}$ & $\begin{array}{c}0.640 \\
(0.480)\end{array}$ \\
\hline Company size & $\begin{array}{c}2.531 \\
(1.208)\end{array}$ & $\begin{array}{c}1.858 \\
(1.082)\end{array}$ & $\begin{array}{c}1.800 \\
(1.013)\end{array}$ & $\begin{array}{c}1.358 \\
(0.783)\end{array}$ & $\begin{array}{c}2.145 \\
(1.227)\end{array}$ & $\begin{array}{c}1.827 \\
(1.102)\end{array}$ \\
\hline $\begin{array}{c}\text { Observations } \\
\% \text { of total }\end{array}$ & $\begin{array}{c}949 \\
18.87\end{array}$ & $\begin{array}{l}1968 \\
39.13\end{array}$ & $\begin{array}{l}285 \\
5.67\end{array}$ & $\begin{array}{l}1655 \\
32.91\end{array}$ & $\begin{array}{c}172 \\
3.42\end{array}$ & $\begin{array}{c}5029 \\
100.00\end{array}$ \\
\hline
\end{tabular}

Source: Authors' calculations using the CHIP-2002 and RUMIC-2007 survey data, urban sample, 7 provinces data, with $16<=$ age $<=60$ for men and $16<=a g e<=55$ for women, full-time employment and earning positive wages.

Note: Ownership categories are state-owned enterprises (SOEs), government agencies or institutions (GAIs), urban collective enterprises (UCEs), private or individual enterprises (PIEs), and foreign-invested enterprises (FIEs). "Experience in current job" stands for the number of years in current occupation. "Company size" measures the number of employees in the company and is grouped into 4 ranks (following CHIP-2002), 1 represents 1-100; 2 represents 101-500; 3 represents 501-1000; 4 represents 1,000 and above. 
Table 3 - Descriptive statistics on individual earnings by ownership

\begin{tabular}{|c|c|c|c|c|c|c|}
\hline 2002 & SOES & GAIs & UCEs & PIEs & FIEs & All \\
\hline Total year income & $\begin{array}{l}11261.6 \\
(7352.8)\end{array}$ & $\begin{array}{l}14221.1 \\
(7992.0)\end{array}$ & $\begin{array}{c}8108.8 \\
(4880.5)\end{array}$ & $\begin{array}{c}9270.9 \\
(9157.6)\end{array}$ & $\begin{array}{r}12907.7 \\
(9617.8)\end{array}$ & $\begin{array}{r}11514.9 \\
(8211.9)\end{array}$ \\
\hline Gap to average earnings & 0,98 & 1,24 & 0,70 & 0,81 & 1,12 & \\
\hline Gini coefficient & 0.307 & 0.290 & 0.293 & 0.386 & 0.324 & 0.336 \\
\hline Working hours/week & $\begin{array}{c}42.30 \\
(7.972)\end{array}$ & $\begin{array}{c}41.23 \\
(8.060)\end{array}$ & $\begin{array}{c}44.38 \\
(10.39)\end{array}$ & $\begin{array}{c}51.94 \\
(15.63)\end{array}$ & $\begin{array}{c}45.34 \\
(11.61)\end{array}$ & $\begin{array}{c}44.52 \\
(11.45)\end{array}$ \\
\hline Hourly wage & $\begin{array}{c}5.380 \\
(4.375)\end{array}$ & $\begin{array}{c}7.086 \\
(6.096)\end{array}$ & $\begin{array}{c}3.710 \\
(2.444)\end{array}$ & $\begin{array}{c}3.851 \\
(4.819)\end{array}$ & $\begin{array}{c}5.877 \\
(4.836)\end{array}$ & $\begin{array}{c}5.434 \\
(5.155)\end{array}$ \\
\hline Gap to average earnings & 0,99 & 1,30 & 0,68 & 0,71 & 1,08 & \\
\hline Gini coefficient & 0.334 & 0.328 & 0.322 & 0.430 & 0.361 & 0.377 \\
\hline Observations & 1896 & 1698 & 393 & 1316 & 127 & 5430 \\
\hline 2007 & SOEs & GAIs & UCEs & PIEs & FIEs & All \\
\hline Total year income & $\begin{array}{c}21614.6 \\
(18204.8)\end{array}$ & $\begin{array}{c}23096.0 \\
(16235.1)\end{array}$ & $\begin{array}{c}18897.0 \\
(12956.8)\end{array}$ & $\begin{array}{c}20492.2 \\
(27264.2)\end{array}$ & $\begin{array}{c}27455.7 \\
(19755.7)\end{array}$ & $\begin{array}{c}21870.7 \\
(20872.9)\end{array}$ \\
\hline Gap to average earnings & 0,99 & 1,06 & 0,86 & 0,94 & 1,26 & \\
\hline Gini coefficient & 0.341 & 0.338 & 0.337 & 0.408 & 0.366 & 0.367 \\
\hline 2002-07 growth rate & $92 \%$ & $62 \%$ & $133 \%$ & $121 \%$ & $113 \%$ & $90 \%$ \\
\hline Working hours/week & $\begin{array}{c}43.24 \\
(9.682)\end{array}$ & $\begin{array}{c}42.19 \\
(19.21)\end{array}$ & $\begin{array}{c}44.65 \\
(10.24)\end{array}$ & $\begin{array}{c}49.87 \\
(22.32)\end{array}$ & $\begin{array}{c}42.61 \\
(7.716)\end{array}$ & $\begin{array}{c}45.07 \\
(18.59)\end{array}$ \\
\hline Hourly wage & $\begin{array}{c}10.13 \\
(9.031)\end{array}$ & $\begin{array}{c}11.58 \\
(11.01)\end{array}$ & $\begin{array}{c}8.826 \\
(6.914)\end{array}$ & $\begin{array}{c}8.947 \\
(11.56)\end{array}$ & $\begin{array}{c}12.81 \\
(9.277)\end{array}$ & $\begin{array}{c}10.33 \\
(10.68)\end{array}$ \\
\hline Gap to average earnings & 0,98 & 1,12 & 0,85 & 0,87 & 1,24 & \\
\hline Gini coefficient & 0.364 & 0.378 & 0.375 & 0.449 & 0.375 & 0.405 \\
\hline 2002-07 growth rate & $88 \%$ & $63 \%$ & $138 \%$ & $132 \%$ & $118 \%$ & $90 \%$ \\
\hline Observations & 949 & 1968 & 285 & 1655 & 172 & 5029 \\
\hline
\end{tabular}

Source: see Table 2.

Notes: Earnings are deflated using the urban provincial-level spatial price deflators calculated by Brandt and Holz (2006), and updated for the year 2007. Base: nationwide prices in 2002. 
Table 4 - Hourly wage functions by ownership, 2002

\begin{tabular}{lccccc}
\hline & $(1)$ & $(2)$ & $(3)$ & $(4)$ & $(5)$ \\
& SOEs & GAIs & UCEs & PIEs & FIEs \\
\hline Gender & $0.104^{* * *}$ & $0.0700^{* *}$ & $0.122^{* *}$ & $0.219^{* * *}$ & 0.145 \\
Education & $(0.000)$ & $(0.012)$ & $(0.041)$ & $(0.000)^{* * *}$ & $(0.201)^{* * *}$ \\
& $0.0621^{* * *}$ & $0.0657^{* * *}$ & $0.0564^{* * *}$ & $0.0759^{* * *}$ & $0.0857^{* * *}$ \\
Experience & $(0.000)$ & $(0.000)$ & $(0.000)$ & $(0.000)^{* * *}$ & $(0.000)$ \\
& $0.0370^{* * *}$ & $0.0422^{* * *}$ & 0.0226 & $0.0380^{* * *}$ & 0.0207 \\
Experience & $(0.000)$ & $(0.000)$ & $(0.116)$ & $(0.000)^{* * *}$ & $(0.365)$ \\
& $-0.000591^{* * *}$ & $-0.000705^{* * *}$ & -0.000391 & $-0.000631^{* *}$ & -0.000223 \\
Experience in & $(0.000)$ & $(0.000)$ & $(0.158)$ & $(0.001)^{* * *}$ & $(0.679)$ \\
current job & 0.00316 & $0.0128^{* * *}$ & 0.00107 & $0.0127^{* * *}$ & 0.00898 \\
Training & $(0.147)$ & $(0.000)$ & $(0.761)$ & $(0.000)$ & $(0.204)$ \\
& $0.200^{* * *}$ & 0.0390 & 0.0914 & 0.0759 & 0.195 \\
Coast & $(0.000)$ & $(0.191)$ & $(0.164)$ & $(0.252)$ & $(0.179)$ \\
& $0.215^{* * *}$ & $0.338^{* * *}$ & $0.161^{* * *}$ & $0.423^{* * *}$ & 0.159 \\
Capital city & $(0.000)$ & $(0.000)$ & $(0.007)$ & $(0.000)$ & $(0.225)$ \\
& $0.200^{* * *}$ & 0.0362 & $0.314^{* * *}$ & $0.264^{* * *}$ & 0.0702 \\
Company size & $(0.000)$ & $(0.225)$ & $(0.000)$ & $(0.000)$ & $(0.600)$ \\
& $0.0354^{* * *}$ & $0.0430^{* * *}$ & 0.0287 & $0.128^{* * *}$ & $0.116^{* *}$ \\
Constant & $(0.003)$ & $(0.001)$ & $(0.262)$ & $(0.000)$ & $(0.021)$ \\
& -0.108 & -0.00987 & -0.0149 & $-0.982^{* * *}$ & -0.413 \\
\hline$N$ & $(0.315)$ & $(0.929)$ & $(0.949)$ & $(0.000)$ & $(0.263)$ \\
$R^{2}$ & 1896 & 1698 & 393 & 1316 & 127 \\
\hline Source: & 0.194 & 0.256 & 0.156 & 0.205 & 0.219 \\
\hline
\end{tabular}

Source: see Table 2.

Notes: see Table 2. $p$-values in parentheses. ${ }^{*} p<0.10,{ }^{* *} p<0.05,{ }^{* * *} p<0.01$. Earnings are deflated using the urban provincial-level spatial price deflators calculated by Brandt and Holz (2006), and updated for the year 2007. Base: nationwide prices in 2002. 
Table 5 - Hourly wage functions by ownership, 2007

\begin{tabular}{lccccc}
\hline & $(1)$ & $(2)$ & $(3)$ & $(4)$ & $(5)$ \\
& SOEs & GAIs & UCEs & PIEs & FIEs \\
\hline Gender & $0.195^{* * *}$ & $0.168^{* * *}$ & $0.212^{* * *}$ & $0.250^{* * *}$ & 0.0771 \\
Education & $(0.000)$ & $(0.000)$ & $(0.005)$ & $(0.000)$ & $(0.407)^{* * *}$ \\
& $0.0381^{* * *}$ & $0.0717^{* * *}$ & $0.0653^{* * *}$ & $0.0500^{* * *}$ & $0.0904^{* * *}$ \\
Experience & $(0.000)$ & $(0.000)$ & $(0.000)$ & $(0.000)$ & $(0.000)$ \\
& $0.0168^{* *}$ & $0.0129^{* *}$ & -0.00463 & $0.0137^{* *}$ & 0.0174 \\
Experience & $(0.047)$ & $(0.049)$ & $(0.748)$ & $(0.031)$ & $(0.474)$ \\
& $-0.000452^{* * *}$ & $-0.000352^{* *}$ & -0.00000205 & $-0.000458^{* * *}$ & -0.000617 \\
Experience in & $(0.009)^{* * *}$ & $(0.014)$ & $(0.995)$ & $(0.00)^{* * *}$ & $(0.318)$ \\
current job & $0.00788^{* * *}$ & $0.0214^{* * *}$ & 0.00599 & $0.0126^{* * *}$ & $0.0336^{* * *}$ \\
Training & $(0.003)$ & $(0.000)$ & $(0.187)$ & $(0.000)$ & $(0.000)$ \\
& $0.197^{* * *}$ & 0.0478 & 0.118 & $0.100^{* * *}$ & 0.102 \\
Coast & $(0.000)$ & $(0.119)$ & $(0.152)$ & $(0.006)$ & $(0.275)$ \\
& $0.341^{* * *}$ & $0.337^{* * *}$ & $0.271^{* * *}$ & $0.384^{* * *}$ & $0.213^{*}$ \\
Capital city & $(0.000)$ & $(0.000)$ & $(0.000)$ & $(0.000)$ & $(0.063)$ \\
& $0.0770^{* *}$ & $0.0629^{* *}$ & $0.183^{* *}$ & $0.184^{* * *}$ & -0.129 \\
Company size & $(0.079)$ & $(0.036)$ & $(0.017)$ & $(0.000)$ & $(0.206)$ \\
& 0.00609 & $0.0359^{* *}$ & 0.0294 & $0.0433^{* *}$ & -0.0482 \\
Constant & $(0.743)$ & $(0.012)$ & $(0.415)$ & $(0.030)$ & $(0.201)$ \\
& $1.028^{* * *}$ & $0.540^{* * *}$ & $0.776^{* *}$ & $0.650^{* * *}$ & 0.689 \\
\hline$N$ & $(0.000)$ & $(0.000)$ & $(0.011)$ & $(0.000)$ & $(0.125)$ \\
$R^{2}$ & 948 & 1964 & 285 & 1652 & 172 \\
\hline Source: & 0.136 & 0.243 & 0.212 & 0.198 & 0.336 \\
\hline
\end{tabular}

Source: see Table 2.

Notes: see Table 4. 
Table 6 - Oaxaca-Blinder decomposition of log hourly wages by ownership

\begin{tabular}{|c|c|c|c|c|c|c|c|c|}
\hline & \multicolumn{2}{|c|}{$\begin{array}{c}\text { Average log } \\
\text { earnings }\end{array}$} & \multirow[t]{2}{*}{$\begin{array}{l}\text { Difference } \\
\text { (A-B) }\end{array}$} & \multicolumn{4}{|c|}{ Decomposition } & \multirow[t]{2}{*}{$\mathrm{N}$} \\
\hline & Group A & Group B & & Explained & Percentage & Unexplained & Percentage & \\
\hline SOEs-GAIs & $\begin{array}{l}1.490 * * * \\
(0.0141)\end{array}$ & $\begin{array}{l}1.762 * * * \\
(0.0154)\end{array}$ & $\begin{array}{c}-0.271 * * * \\
(0.0209)\end{array}$ & $\begin{array}{c}0.0115 \\
(0.0150)\end{array}$ & $-4.2 \%$ & $\begin{array}{c}-0.283^{* * *} \\
(0.0219)\end{array}$ & $104.2 \%$ & 3594 \\
\hline SOEs-UCEs & $\begin{array}{l}1.490 * * * \\
(0.0141)\end{array}$ & $\begin{array}{l}1.139 * * * \\
(0.0293)\end{array}$ & $\begin{array}{l}0.351 * * * \\
(0.0325)\end{array}$ & $\begin{array}{l}0.105 * * * \\
(0.0182)\end{array}$ & $29.9 \%$ & $\begin{array}{l}0.246 * * * \\
(0.0324)\end{array}$ & $70.1 \%$ & 2289 \\
\hline SOEs-PIEs & $\begin{array}{l}1.490 * * * \\
(0.0141)\end{array}$ & $\begin{array}{l}0.973 * * * \\
(0.0266)\end{array}$ & $\begin{array}{l}0.517 * * * \\
(0.0301)\end{array}$ & $\begin{array}{l}0.256^{* * *} \\
(0.0189)\end{array}$ & $49.5 \%$ & $\begin{array}{l}0.261 * * * \\
(0.0274)\end{array}$ & $50.5 \%$ & 3212 \\
\hline SOEs-FIEs & $\begin{array}{l}1.490 * * * \\
(0.0141)\end{array}$ & $\begin{array}{l}1.547 * * * \\
(0.0587)\end{array}$ & $\begin{array}{l}-0.0566 \\
(0.0604)\end{array}$ & $\begin{array}{l}-0.00777 \\
(0.0262)\end{array}$ & $13.7 \%$ & $\begin{array}{l}-0.0488 \\
(0.0556)\end{array}$ & $86.3 \%$ & 2023 \\
\hline GAIs-UCEs & $\begin{array}{l}1.762 * * * \\
(0.0154)\end{array}$ & $\begin{array}{l}1.139 * * * \\
(0.0293)\end{array}$ & $\begin{array}{l}0.622 * * * \\
(0.0331)\end{array}$ & $\begin{array}{c}0.0726^{* * *} \\
(0.0200)\end{array}$ & $11.7 \%$ & $\begin{array}{l}0.550 * * * \\
(0.0340)\end{array}$ & $88.3 \%$ & 2091 \\
\hline GAIs-PIEs & $\begin{array}{l}1.762 * * * \\
(0.0154)\end{array}$ & $\begin{array}{l}0.973 * * * \\
(0.0266)\end{array}$ & $\begin{array}{l}0.789 * * * \\
(0.0307)\end{array}$ & $\begin{array}{c}0.217 * * * \\
(0.0194)\end{array}$ & $27.5 \%$ & $\begin{array}{l}0.572 * * * \\
(0.0307)\end{array}$ & $72.5 \%$ & 3014 \\
\hline GAIs-FIEs & $\begin{array}{l}1.762 * * * \\
(0.0154)\end{array}$ & $\begin{array}{l}1.547 * * * \\
(0.0587)\end{array}$ & $\begin{array}{l}0.215 * * * \\
(0.0607)\end{array}$ & $\begin{array}{c}0.0323 \\
(0.0308)\end{array}$ & $15.0 \%$ & $\begin{array}{l}0.183 * * \\
(0.0589)\end{array}$ & $85.0 \%$ & 1825 \\
\hline UCEs-PIEs & $\begin{array}{l}1.139 * * * \\
(0.0293)\end{array}$ & $\begin{array}{l}0.973 * * * \\
(0.0266)\end{array}$ & $\begin{array}{l}0.166 * * * \\
(0.0396)\end{array}$ & $\begin{array}{c}0.119 * * * \\
(0.0242)\end{array}$ & $71.7 \%$ & $\begin{array}{c}0.0473 \\
(0.0369)\end{array}$ & $28.3 \%$ & 1709 \\
\hline UCEs-FIEs & $\begin{array}{c}1.139 * * * \\
(0.0293)\end{array}$ & $\begin{array}{c}1.547 * * * \\
(0.0588)\end{array}$ & $\begin{array}{c}-0.408 * * * \\
(0.0657)\end{array}$ & $\begin{array}{c}-0.178 * * * \\
(0.0428)\end{array}$ & $43.6 \%$ & $\begin{array}{c}-0.230 * * * \\
(0.0665)\end{array}$ & $56.4 \%$ & 520 \\
\hline PIEs-FIEs & $\begin{array}{c}0.973 * * * \\
(0.0266)\end{array}$ & $\begin{array}{c}1.547 * * * \\
(0.0587)\end{array}$ & $\begin{array}{c}-0.574 * * * \\
(0.0645)\end{array}$ & $\begin{array}{c}-0.334 * * * \\
(0.0439) \\
\end{array}$ & $58.2 \%$ & $\begin{array}{c}-0.240 * * * \\
(0.0607)\end{array}$ & $41.8 \%$ & 1443 \\
\hline
\end{tabular}


Table 6 (cont') - Oaxaca-Blinder decomposition of log hourly wages by ownership

Year 2007

\begin{tabular}{|c|c|c|c|c|c|c|c|c|}
\hline & \multicolumn{2}{|c|}{$\begin{array}{c}\text { Average log } \\
\text { earnings }\end{array}$} & \multirow[t]{2}{*}{$\begin{array}{l}\text { Difference } \\
\text { (A-B) }\end{array}$} & \multicolumn{4}{|c|}{ Decomposition } & \multirow[t]{2}{*}{$\mathrm{N}$} \\
\hline & Group A & Group B & & Explained & Percentage & Unexplained & Percentage & \\
\hline SOEs-GAIs & $\begin{array}{c}2.081 * * * \\
(0.0233)\end{array}$ & $\begin{array}{c}2.194 * * * \\
(0.0162)\end{array}$ & $\begin{array}{c}-0.113^{* * *} \\
(0.0284)\end{array}$ & $\begin{array}{l}-0.0121 \\
(0.0157)\end{array}$ & $10.7 \%$ & $\begin{array}{c}-0.101 * * * \\
(0.0297)\end{array}$ & $89.3 \%$ & 2912 \\
\hline SOEs-UCEs & $\begin{array}{c}2.081 * * * \\
(0.0233)\end{array}$ & $\begin{array}{c}1.946^{* * * *} \\
(0.0394)\end{array}$ & $\begin{array}{l}0.135 * * \\
(0.0458)\end{array}$ & $\begin{array}{l}0.0496^{*} \\
(0.0235)\end{array}$ & $36.7 \%$ & $\begin{array}{c}0.0854 \\
(0.0461)\end{array}$ & $63.3 \%$ & 1233 \\
\hline SOEs-PIEs & $\begin{array}{c}2.081 * * * \\
(0.0233)\end{array}$ & $\begin{array}{c}1.846^{* * * *} \\
(0.0191)\end{array}$ & $\begin{array}{c}0.235 * * * \\
(0.0301)\end{array}$ & $\begin{array}{c}0.140 * * * \\
(0.0237)\end{array}$ & $59.6 \%$ & $\begin{array}{c}0.0955 * * \\
(0.0349)\end{array}$ & $40.4 \%$ & 2600 \\
\hline SOEs-FIEs & $\begin{array}{c}2.081 * * * \\
(0.0233)\end{array}$ & $\begin{array}{c}2.312 * * * \\
(0.0532)\end{array}$ & $\begin{array}{c}-0.231 * * * \\
(0.0581)\end{array}$ & $\begin{array}{c}-0.0976^{* *} \\
(0.0333)\end{array}$ & $42.3 \%$ & $\begin{array}{l}-0.134 * \\
(0.0598)\end{array}$ & $57.7 \%$ & 1120 \\
\hline GAIs-UCEs & $\begin{array}{c}2.194 * * * \\
(0.0162)\end{array}$ & $\begin{array}{l}1.946^{* * * *} \\
(0.0394)\end{array}$ & $\begin{array}{c}0.248 * * * \\
(0.0426)\end{array}$ & $\begin{array}{c}0.125 * * * \\
(0.0223)\end{array}$ & $50.4 \%$ & $\begin{array}{l}0.123 * * \\
(0.0398)\end{array}$ & $49.6 \%$ & 2249 \\
\hline GAIs-PIEs & $\begin{array}{c}2.194 * * * \\
(0.0162)\end{array}$ & $\begin{array}{l}1.846^{* * * *} \\
(0.0191)\end{array}$ & $\begin{array}{c}0.348 * * * \\
(0.0250)\end{array}$ & $\begin{array}{c}0.232 * * * \\
(0.0162)\end{array}$ & $66.7 \%$ & $\begin{array}{c}0.116^{* * * *} \\
(0.0244)\end{array}$ & $33.3 \%$ & 3616 \\
\hline GAIs-FIEs & $\begin{array}{c}2.194 * * * \\
(0.0162)\end{array}$ & $\begin{array}{c}2.312 * * * \\
(0.0532)\end{array}$ & $\begin{array}{l}-0.118 * \\
(0.0556)\end{array}$ & $\begin{array}{c}-0.00764 \\
(0.0308)\end{array}$ & $6.5 \%$ & $\begin{array}{l}-0.111 * \\
(0.0494)\end{array}$ & $93.5 \%$ & 2136 \\
\hline UCEs-PIEs & $\begin{array}{l}1.946 * * * \\
(0.0394)\end{array}$ & $\begin{array}{l}1.846 * * * \\
(0.0191)\end{array}$ & $\begin{array}{c}0.100 * \\
(0.0438)\end{array}$ & $\begin{array}{c}0.0886 * * * \\
(0.0229)\end{array}$ & $88.6 \%$ & $\begin{array}{c}0.0114 \\
(0.0406)\end{array}$ & $11.4 \%$ & 1937 \\
\hline UCEs-FIEs & $\begin{array}{l}1.946 * * * \\
(0.0394)\end{array}$ & $\begin{array}{c}2.312 * * * \\
(0.0532)\end{array}$ & $\begin{array}{c}-0.366^{* * *} \\
(0.0663)\end{array}$ & $\begin{array}{c}-0.180 * * * \\
(0.0414)\end{array}$ & $49.2 \%$ & $\begin{array}{l}-0.186 * * \\
(0.0647)\end{array}$ & $50.8 \%$ & 457 \\
\hline PIEs-FIEs & $\begin{array}{c}1.846^{* * * *} \\
(0.0191)\end{array}$ & $\begin{array}{c}2.312 * * * \\
(0.0532)\end{array}$ & $\begin{array}{c}-0.466^{* * *} \\
(0.0565) \\
\end{array}$ & $\begin{array}{c}-0.254 * * * \\
(0.0319) \\
\end{array}$ & $54.5 \%$ & $\begin{array}{c}-0.212^{* * *} \\
(0.0528)\end{array}$ & $45.5 \%$ & 1824 \\
\hline
\end{tabular}

Source: see Table 2 .

Notes: See Table 2. Standard errors in parentheses. ${ }^{*} p<0.05,{ }^{* *} p<0.01,{ }^{* * *} p<0.001$. Decompositions based on regressions results presented in Tables 4 and 5. Earnings are deflated using the urban provincial-level spatial price deflators calculated by Brandt and Holz (2006), and updated for the year 2007. Base: nationwide prices in 2002. 
Figure 1 - Average annual real wage trend for public and private sectors, 1995-2007

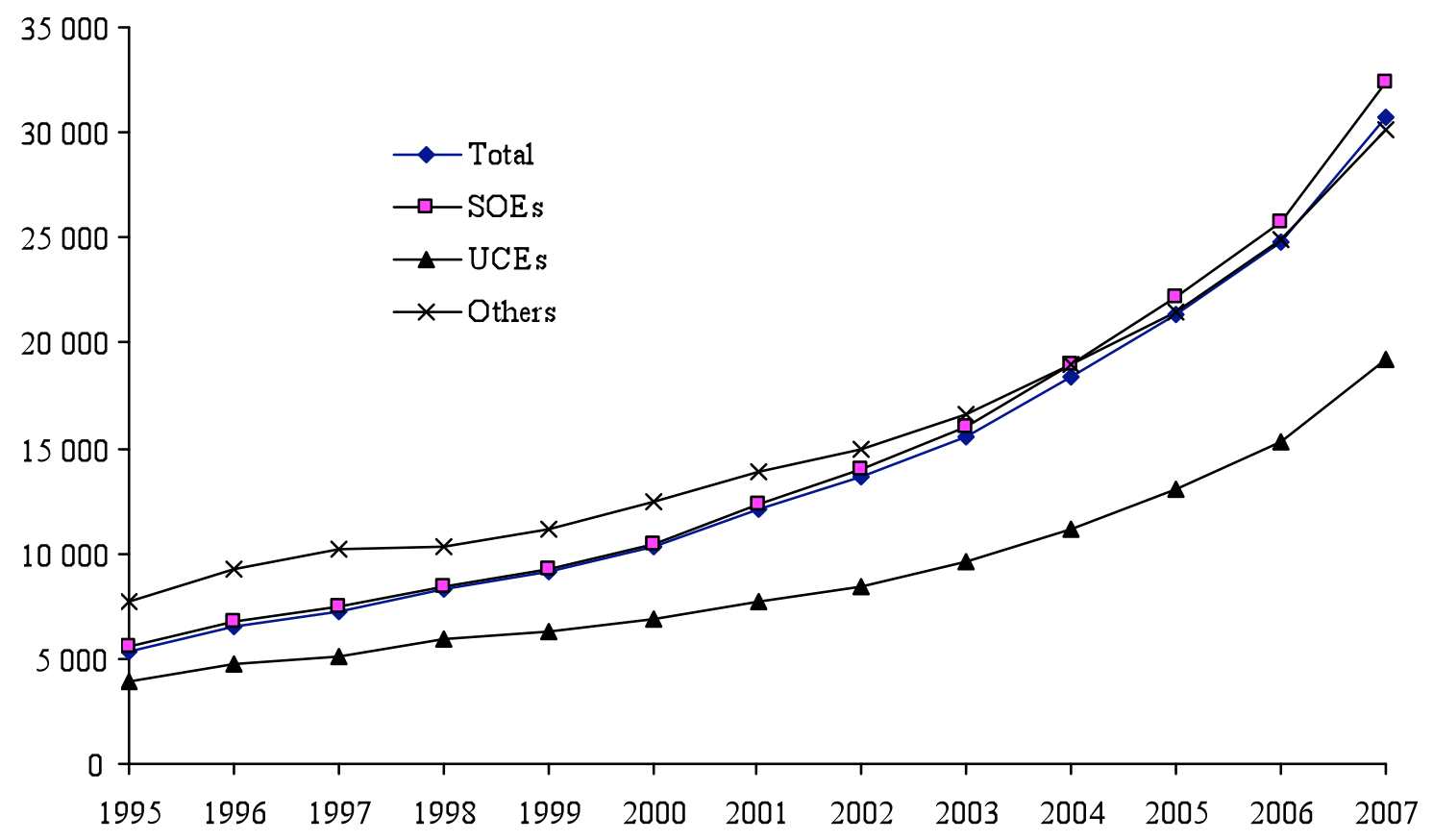

Source: China Statistical Yearbook, 2008.

Note: In national statistics, wages refer to the "total remuneration for labor paid by all organizations directly to all staff and workers of those entities". The reported classification by ownership does not distinguish foreign invested enterprises and private enterprises, which are all included in the category "others". Average annual wages of staff and workers are deflated by the urban consumer price index $(1995=100)$. 


\section{Figure 2 - Kernel density estimations for the distribution of income by ownership category, 2002 and 2007}

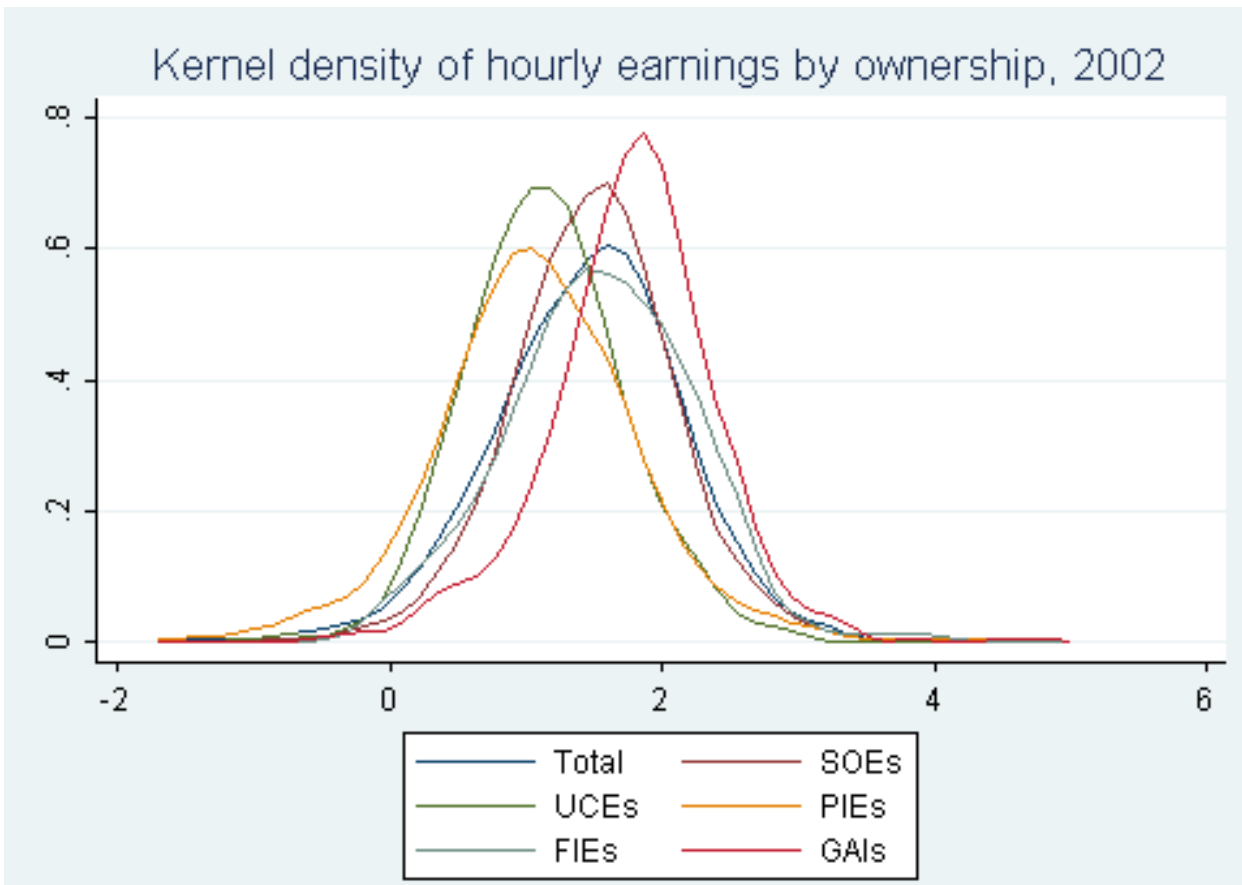

Kernel density of hourly earnings by ownership, 2007

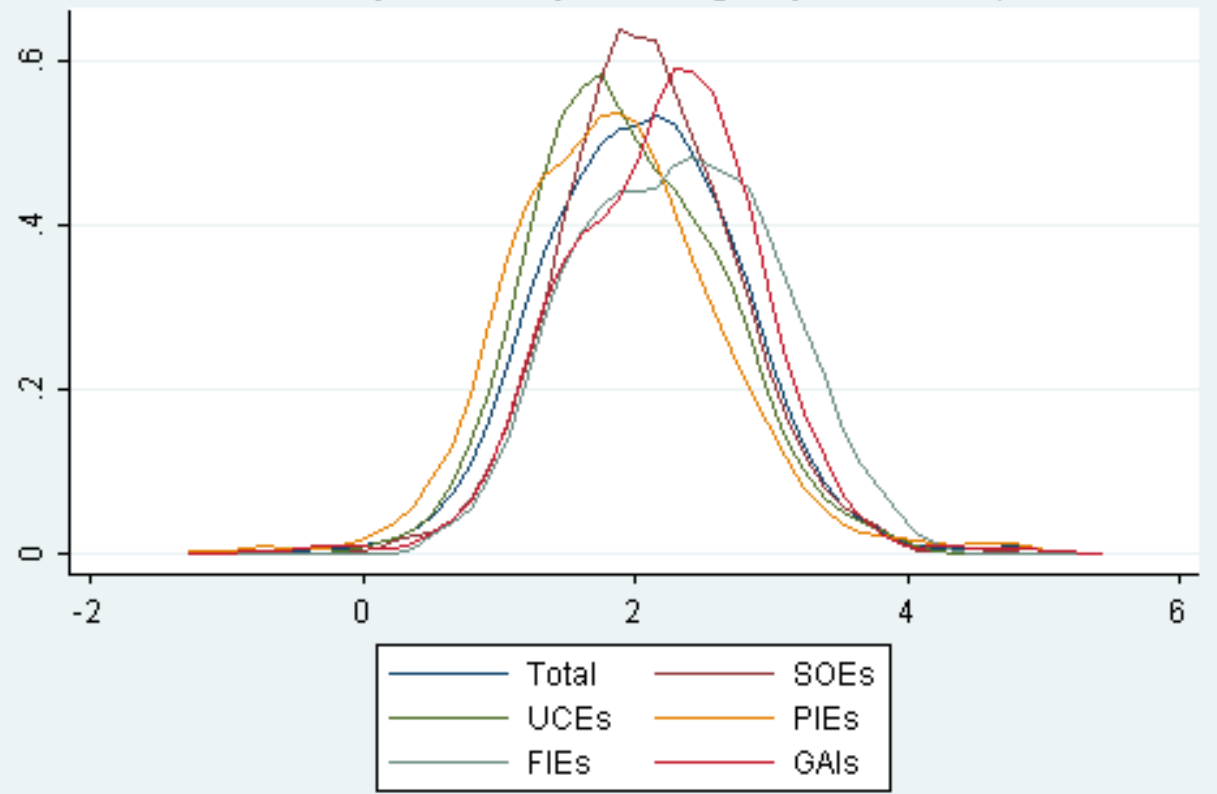

Source: Authors' calculations using the CHIP-2002 and RUMIC-2007 survey data.

Note: See Table 2. Earnings are deflated using the urban provincial-level spatial price deflators calculated by Brandt and Holz (2006), and updated for the year 2007. Base: nationwide prices in 2002. 
Figure 3 - Juhn-Murphy-Pierce decomposition of log hourly wages by ownership
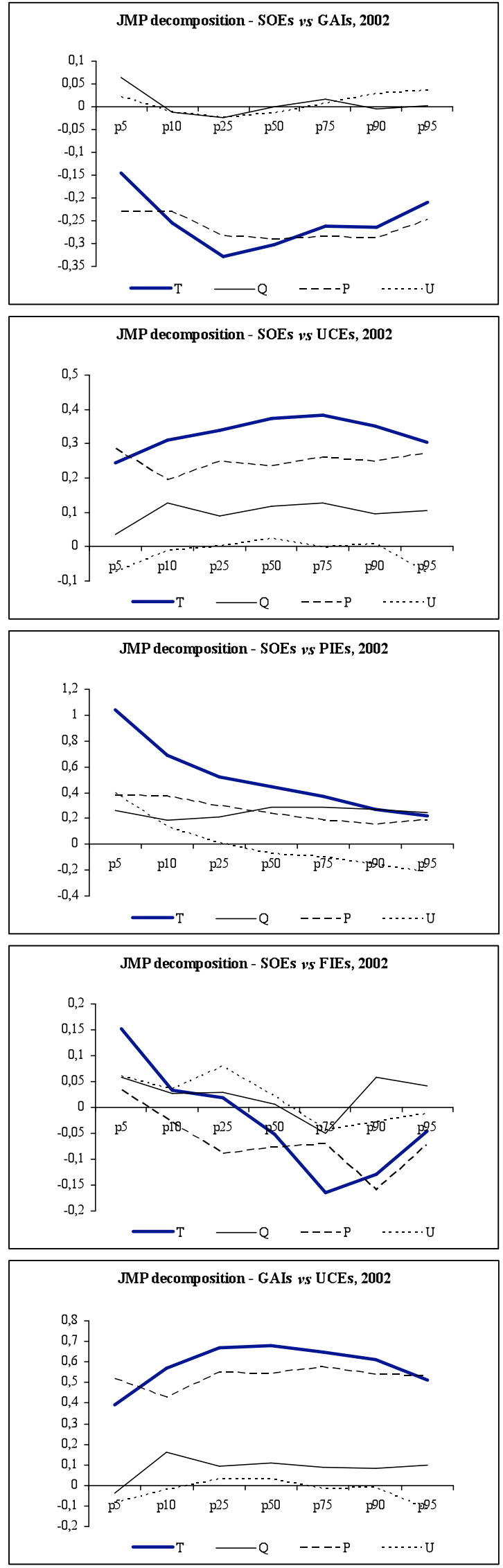
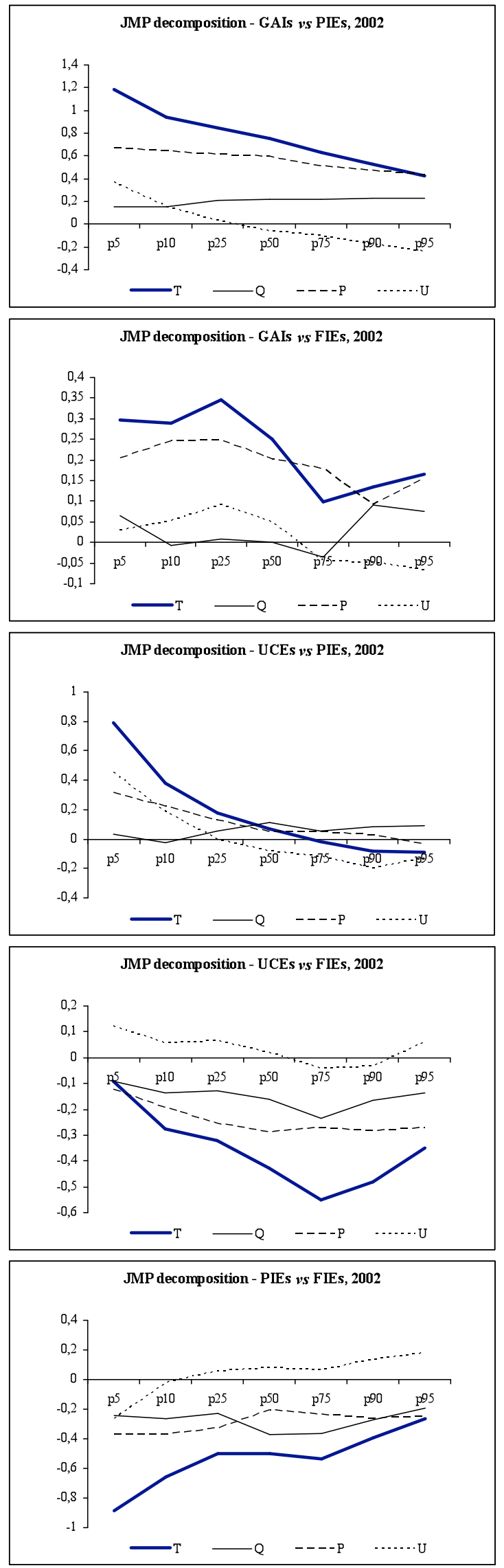

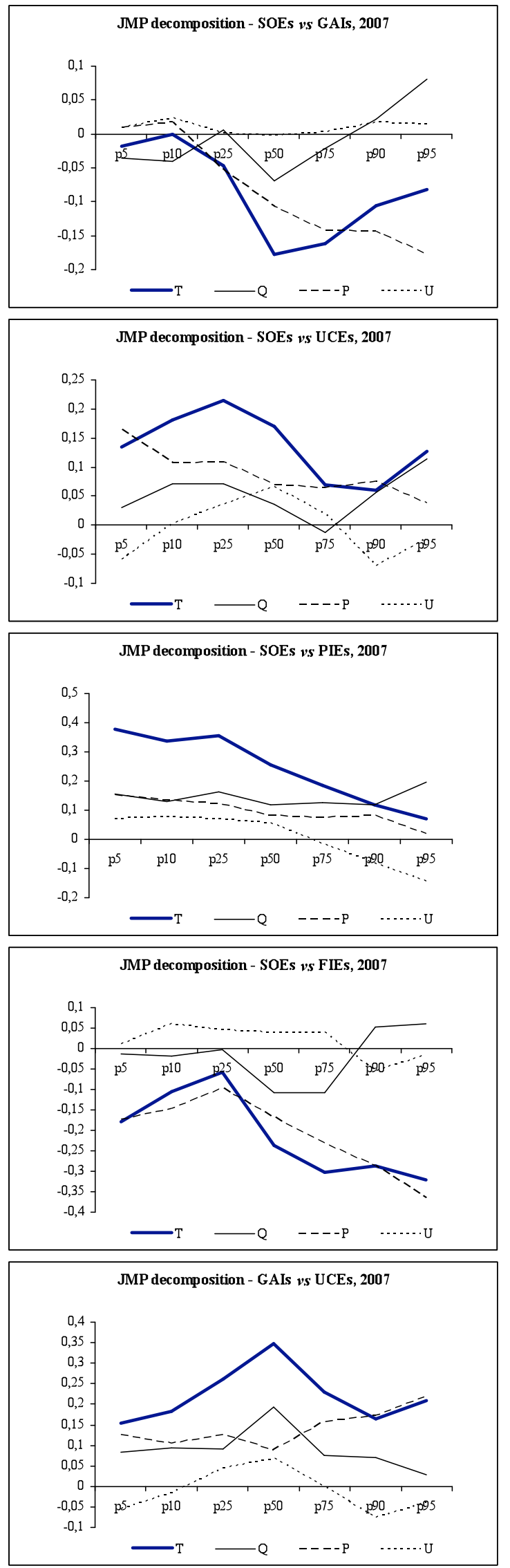
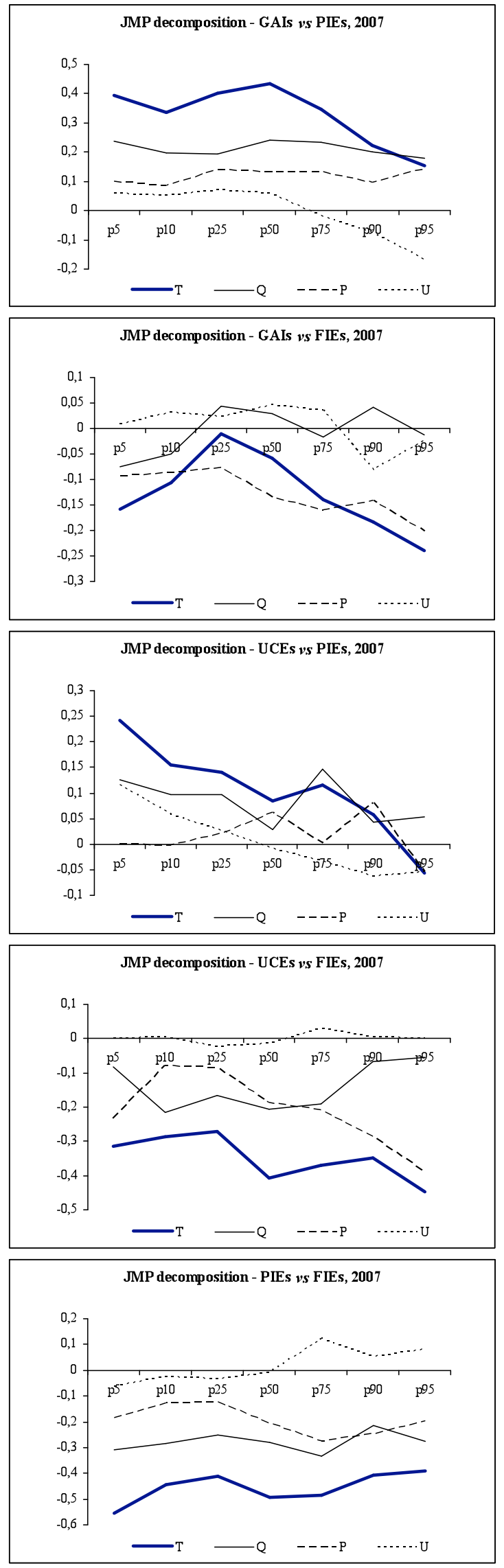